\title{
PEMBENTUKAN KARAKTER SISWA MELALUI PROGRAM LISA, LIBRA, PATUJAR DI SMPN 1 CILAMAYA WETAN
}

\author{
${ }^{1}$ Lusiana Rahmatiani \\ ${ }^{1}$ Dosen Pendidikan Pancasila dan Kewarganegaraan \\ Fakultas Keguruan dan Ilmu Pendidikan \\ Universitas Buana Perjuangan Karawang \\ Email: lusianarahmatiani@yahoo.com
}

\begin{abstract}
Character education is one of the focus of educational goals in Indonesia. The importance of character education because of the declining ethics, morale of learners and the increasing popularity of student delinquency, such as brawl and drug addicts. Implementation of character education is very important to evaluate how the process and results. The research was conducted at SMPN 1 Cilamaya Wetan. The purpose of this study describes the implementation of lisa program, libra, patujar applied in SMPN 1 Cilamaya Wetan. Knowing the value of characters generated in the program lisa, libra, patujar applied in SMPN 1 Cilamaya Wetan. The research method used is qualitative method with data collection technique, observation, interview and documentation. Suggestion of research result that is importance of socialization about character education to learners, teachers and society to support the embodiment of school program libra libra patujar. Schools should involve parents and community as partners in the coaching and habituation of student characters.
\end{abstract}

Keywords: Character Education, Character Value, Lisa, Libra Patujar

\begin{abstract}
ABSTRAK
Pendidikan karakter merupakan salah satu fokus tujuan pendidikan di Indonesia. Pentingnya pendidikan karakter karena semakin menurunnya etika, moral peserta didik dan semakin maraknya kenakalan pelajar, seperti tawuran dan pecandu narkoba. Implementasi pendidikan karakter sangat penting untuk dievaluasi bagaimana proses dan hasilnya. Penelitian dilakukan di SMPN 1 Cilamaya Wetan. Tujuan penelitian ini mendeskripsikan implementasi program lisa, libra, patujar yang diterapkan di SMPN 1 Cilamaya Wetan. Mengetahui nilai karakter yang dihasilkan dalam program lisa, libra, patujar yang diterapkan di SMPN 1 Cilamaya Wetan. Metode penelitian yang dipergunakan adalah metode kualitatif dengan teknik pengumpulan data, observasi, wawancara dan dokumentasi. Saran hasil penelitian yaitu pentingnya sosialisasi mengenai pendidikan karakter kepada peserta didik, guru dan masyarakat untuk menunjang keterwujudan program sekolah lisa libra patujar. Sekolah harus melibatkan orang tua dan masyarakat sebagai partner dalam pembinaan dan pembiasaan karakter siswa.
\end{abstract}

\section{Kata Kunci : Pendidikan Karakter, Nilai Karakter, Lisa, Libra Patujar}

\section{PENDAHULUAN}

Mengenai penelitian pembentukan karakter siswa melalui program Lisa, Libra, dan Patujar penting untuk dilakukan penelitian karena sejumlah alasan. Pertama, buruknya citra sekolah dikalangan masyarakat yang diakibatkan oleh tindakan siswa yang membuang sampah sembarangan. Kedua, 
banyak siswa yang seakan tidak peduli dengan lingkungan sekitar. Ketiga, banyaknya siswa yang berkeliaran diluar jam sekolah sehingga meningkatkan citra buruk masyarakat terhadap sekolah. Keempat, munculnya ketidakpercayaan terhadap sekolah yang menjadikan rendahnya tingkat partisipasi masyarakat dalam mendukung program sekolah.

Pendidikan secara umum berarti daya upaya untuk memajukan tumbuhnya budi pekerti (kekuatan batin dan karakter), pikiran (intelek) dan tubuh anak. Dalam pengertian ini mengandung makna bahwa pendidikan pada siswa tidak boleh dipisah-pisahkan, tetapi sebagai suatu kesatuan untuk memajukan kesempurnaan hidup, yakni kehidupan dan penghidupan anakanak yang kita didik selaras dengan dunianya.

Proses belajar dapat terjadi di mana saja sepanjang hayat. Sekolah merupakan salah satu tempat proses belajar terjadi. Sekolah merupakan tempat kebudayaan, karena pada dasarnya proses belajar merupakan proses pembudayaan. Dalam hal ini, proses pembudayaan di sekolah adalah untuk pencapaian akademik siswa, untuk membudayakan sikap, pengetahuan, keterampilan dan tradisi yang ada dalam suatu komunitas budaya, serta untuk mengembangkan budaya dalam suatu komunitas melalui pencapaian akademik siswa. Pendidikan kewarganegaraan di sekolah menengah pertama merupakan mata pelajaran umum yang menjadi hak bagi siswa sebagai peserta didik untuk mendapatkannya dan merupakan kewajiban sekolah untuk memuat

pendidikan kewarganegaraan

dalam

kurikulumnya.

Menurut Muhazir, mengungkapkan dengan adanya program pemerintah mengenai Penguatan Pendidikan Karakter yang digulirkan bersamaan dengan peraturan menteri pendidikan dan kebudayaan (Permendikbud) Nomor 23 Tahun 2017 tentang Hari Sekolah yang tetap berlaku sambil menunggu terbitnya Perpres tentang Penguatan Pendidikan Karakter (PPK). Dengan dasar Penguatan Pendidikan Karakter (PPK) yang digulirkan pemerintah diharapkan dapat membantu sekolah menjadi wadah untuk proses pembentukan karakter siswa sebagai generasi penerus bangsa yang lebih baik akan dirasa sangat baik dengan adanya dukungan program dari pemerintah. Penguatan Pendidikan Karakter (PPK) adalah program gerakan pendidikan disekolah untuk memperkuat karakter siswa melalui harmonisasi olah hati (etik) olah rasa (estetik), olah pikir (literasi) dan olah raga (kinestetik) dengan dukungan pelibatan publik dan kerjasama antara sekolah, keluarga dan masyarakat yang merupakan bagian dari gerakan nasional revolusi mental (Kemendikbud, 2017).

Berangkat dari paparan diatas, maka adanya korelasi dan sinergitas antara program yang digulirkan pemerintah PPK dengan program yang digulirkan oleh Ahmad Fadloli, M.Pd selaku kepala sekolah SMPN 1 Cilamaya Wetan yang membuat sebuah kebijakan dengan program unggulan sekolah yang diberi nama Lisa, Libra, Patujar. Karena program tersebut dianggap yang paling relevan dengan kondisi dan keadaan yang sebenarnya di lapangan. Kebijakan dikeluarkannya Lisa, Libra, Patujar 
oleh kepala sekolah merupakan salah satu upaya untuk menciptakan sebuah terobosan yang baik untuk membentuk karakter siswa dengan dasar program PPK yang digulirkan pemerintah.

Proses pembelajaran yang dilaksanakan di sekolah ini tidak berbeda dengan sekolah lain pada umumnya namun sekolah SMPN 1 Cilamaya Wetan mempunyai program unggulan yaitu Lisa, Libra, Patujar yang digulirkan oleh kepala sekolah sejak tahun ajaran 2016/2017 dimana program tersebut menjadi kebijakan sekolah untuk membantu membentuk karakter siswa. Sesuai dengan Permendikbud No 23 tahun 2015 pasal 1 tentang penumbuhan budi pekerti :

"Penumbuhan Budi Pekerti yang selanjutnya disingkat PBP adalah kegiatan pembiasaan sikap dan perilaku positif di sekolah yang dimulai sejak dari hari pertama sekolah, masa orientasi peserta didik baru untuk jenjang sekolah menengah pertama, sekolah menengah atas dan sekolah menengah kejuruan, sampai dengan kelulusan sekolah".

Selain dalam proses pembelajaran adanya penerapan program unggulan yang memiliki keunggulan karakter sebagai berikut:
a. Lisa (Lihat Sampah Ambil)
b. Libra (Lihat Berantakan Rapihkan)
c. Patujar (Tepat Waktu Belajar)

Tiga unsur karakter terpuji di atas, selaras dengan 18 nilai karakter dari kemendikbud. Dengan adanya program LISA (Lihat Sampah Ambil) bertujuan untuk penguatan karakter peduli lingkungan bagi seluruh warga sekola terkait dengan kebiasaan membuang sampah sembarangan yang berdampak sosial. LIBRA (Lihat Berantakan Rapikan), program ini digulirkan dengan tujuan untuk penguatan karakter peduli lingkungan bagi seluruh warga sekolah terkait kesadaran pentingnya lingkungan sekolah yang tertata rapi berdasarkan fungsinya masingmasing. PATUJAR (Tepat Waktu Belajar) program ini digulirkan dengan tujuan untuk penguatan karakter disiplin terkait disiplin waktu dalam proses belajar mengajar berdasarkan jadwal waktu belajar yang sudah ditetapkan (Fadloli Ahmad, 2016).

Karakter adalah watak, tabiat, akhlak, atau kepribadian seseorang yang terbentuk dari hasil internalisasi berbagai kebajikan (virtues) yang diyakini dan digunakan sebagai landasan untuk cara pandang, berpikir, bersikap, dan bertindak. Kebajikan terdiri atas sejumlah nilai, moral, dan norma, seperti jujur, berani bertindak, dapat dipercaya, dan hormat kepada orang lain. Interaksi seseorang dengan orang lain menumbuhkan karakter masyarakat dan karakter bangsa.

Karakter merupakan perilaku manusia yang berhubungan dengan Tuhan Yang Maha Esa, diri sendiri, sesama manusia, lingkungan, dan kebangsaan yang terwujud dalam pikiran, sikap, perasaan, perkataan, dan perbuatan berdasarkan normanorma agama, hukum, tata krama, budaya, dan adat istiadat. Orang yang perilakunya sesuai dengan norma-norma disebut berkarakter mulia. Karakter mulia berarti individu memiliki pengetahuan tentang potensi dirinya, yang ditandai dengan nilai-nilai seperti 
reflektif, percaya diri, rasional, logis, kritis, analitis, kreatif dan inovatif, mandiri, hidup sehat, bertanggung jawab, cinta ilmu, sabar, berhati-hati, rela berkorban, pemberani, dapat dipercaya, jujur, menepati janji, adil, rendah hati, dan nilai-nilai lainnya. Individu juga memiliki kesadaran untuk berbuat yang terbaik atau unggul, dan individu juga mampu bertindak sesuai potensi dan kesadarannya tersebut.

Pendidikan karakter bisa dikatakan sebagai sebuah usaha untuk menghidupkan spiritual yang ideal. Foerster seorang ilmuan pernah mengatakan bahwa tujuan utama dari pendidikan adalah untuk membentuk karakter karena karakter merupakan suatu evaluasi seorang pribadi atau individu serta karakter pun dapat memberi kesatuan atas kekuatan dalam mengambil sikap di setiap situasi. Pendidikan karakter pun dapat dijadikan sebagai strategi untuk mengatasi pengalaman yang selalu berubah sehingga mampu membentuk identitas yang kokoh dari setiap individu dalam hal ini dapat dilihat bahwa tujuan pendidikan karakter ialah untuk membentuk sikap yang dapat membawa kita kearah kemajuan tanpa harus bertentangan dengan norma yang berlaku (dalam Kusuma, Doni. 2007 : 3-5).

Relevansi pengadopsian program lisa, libra, patujar dalam pembentukan karakter siswa adalah sebagai upaya inovasi sekolah yang diciptakan oleh kepala sekolah untuk menjadi program unggulan sekolah. Program lisa, libra, patujar menjadi pondasi awal pembiasaan dalam orientasi pembentukan karakter siswa yang sesuai dengan program pemerintah tentang penguatan pendidikan karakter (PPK) yang berlandaskan pada Peraturan Presiden No 87 tahun 2017 tentang Penguatan Pendidikan Karakter pasal 1 ayat 1 :

"Penguatan Pendidikan Karakter yang selanjutnya disingkat PPK adalah gerakan pendidikan dibawah tanggung jawab satuan pendidikan untuk memperkuat karakter peserta didik melalui harmonisasi olah hati, olah pikir, olah karsa, dan olah raga dengan pelibatan dan kerjasama antara satuan pendidikan, keluarga, dan masyarakat sebagai bagian dari Gerakan Nasional Revolusi Mental (GNRM)".

Penguatan pendidikan karakter hadir untuk menyiapkan generasi emas 2045 yang memiliki kecakapan moral, etika dan budi pekerti yang baik. Dengan menempatkan kembali karakter sebagai ruh dari pendidikan di Indonesia yang berdampingan dengan kecakapan intelektual. Penguatan Pendidikan Karakter berperan dalam pembentukan generasi muda yang tangguh, cerdas dan berkarakter.

Rasionalisasi program pemerintah mengenai Penguatan Pendidikan Karakter (PPK), yaitu

a. Undang-undang No 20 Tahun 2003 Pasal 3

Pendidikan nasional berfungsi mengembangkan kemampuan dan membentuk watak serta peradaban bangsa yang bermartabat dalam rangka mencerdaskan kehidupan bangsa, 
bertujuan untuk mengembangkan potensi peserta didik agar menjadi manusia yang beriman dan bertakwa kepada tuhan yang maha esa, berakhlak mulia, berilmu, cakap, kreatif, mandiri, dan menjadi warga negara yang demokratis serta bertanggung jawab.

b. Agenda Nawacita No 8 . Melakukan revolusi karakter bangsa melalu penataan kembali kurikulum pendidikan nasional.

c. Penguatan revolusi karakter bangsa melalui budi pekerti dan pembangunan karakter peserta didik sebagai bagian dari revolusi mental.

d. Trisakti

Mewujudkan generasi yang berkepribadian dalam kebudayaan

e. RPJMN 2015-2019

Penguatan pendidikan karakter pada anak-anak usia sekolah pada semua jenjang pendidikan untuk memperkuat nilai-nilai moral, akhlak dan kepribadian peserta didik dengan memperkuat pendidikan karakter yang terintegrasi kedalam mata pelajaran

f. Presiden No 87 tahun 2017 pasal 1 (1) tentang Penguatan Pendidikan Karakter: "Penguatan Pendidikan Karakter yang selanjutnya disingkat PPK adalah gerakan pendidikan dibawah tanggung jawab satuan pendidikan untuk memperkuat karakter peserta didik melalui harmonisasi olah hati, olah rasa, olah rasa, dan olah raga dengan pelibatan dan kerjasama antara satuan pendidikan, keluarga, dan masyarakat sebagai bagian dari Gerakan Nasional Revolusi Mental (GNRM)".

g. Mempersiapkan Generasi Emas 2045

Yang bertakwa, nasionalis, tangguh, mandiri dan memiliki keunggulan bersaing secara global

h. Arahan Khusus presiden kepada mendikbud Untuk memperkuat pendidikan karakter

\section{Rumusan Masalah}

Berdasarkan latar belakang yang telah diuraikan, dapat di identifikasikan perumusan permasalahan yang relevan dalam penelitian ini. Bagaimana pembentukan karakter siswa melalui program lisa, libra, patujar di lingkungan SMP Negeri 1 Cilamaya Wetan di Kabupaten Karawang?. Adapun subpokok rumusan masalah "Bagaimana nilai karakter siswa yang dihasilkan dalam program lisa, libra, patujar yang diterapkan di SMPN 1 Cilamaya Wetan?".

\section{Tujuan Penelitian}

Menindak lanjuti dari fokus penelitian, maka tujuan penelitian yang akan dilakukan ini adalah untuk mengetahui nilai karakter yang dihasilkan dalam program lisa, libra, 
patujar yang diterapkan di SMPN 1 Cilamaya Wetan.

\section{METODE}

Metode penelitian ini menggunakan pendekatan kualitatif dengan metode studi kasus. Subjek dalam penelitian ini terdiri dari tiga kategori, yakni manusia, proses dan latar. Penentuan ketiga kategori tersebut didasarkan pada pandangan Alwasilah (2012:102) yang menjelaskan bahwa dalam penelitian pemilihan sampel bukan saja diterapkan pada manusia sebagai responden, melainkan juga latar (setting), serta kejadian dan proses. Subjek penelitian dari unsur manusia yang dijadikan responden, peneliti membagi menjadi tiga unsur, meliputi unsur akademisi (guru), siswa dan masyarakat. Semua subjek tersebut diseleksi berdasarkan kompetensi, tugas, pokok dan fungsi yang diembannya serta dianggap dapat memberikan sejumlah informasi terkait dengan penelitian pembentukan karakter siswa melalui program lisa, libra, patujar di SMPN 1 Cilamaya Wetan. Lokasi penelitian terletak di sekolah SMPN 1 Cilamaya Wetan di Jalan Raya Cilamaya, desa mekarmaya, kecamatan cilamaya wetan kabupaten karawang provinsi jawa barat.

Penelitian yang dilakukan penulis yaitu penelitian dengan menggunakan metode studi kasus. Gay dkk (2009:426) mengemukan metode studi kasus sebagai " $a$ qualitative approach to studying a phenomenon, focused on a unit of studi or a bounded system, not a methodological choice, but a choice of what to study, an allencompassing research method". Melalui pemahaman ini dapat dijelaskan bahwa penelitian studi kasus merupakan pendekatan kualitatif yang digunakan untuk mempelajari fenomena yang terfokus atau terbatas pada satu unit penelitian, serta merupakan metode penelitian yang mencakup secara keseluruhan penelitian. Alwasilah (2012:65) menjelaskan bahwa "penelitian kualitatif lazimnya berkonsentrasi pada sejumlah orang atau situasi yang relatif sedikit dan perhatiannya terkuras habis-habisan pada analisis kekhasan kelompok atau situasi itu saja.

\section{HASIL DAN PEMBAHASAN}

Berdasarkan data hasil temuan di lapangan yang diperoleh melalui wawancara, observasi dan studi dokumentasi, pada bagian ini akan dikemukakan hasil analisis terhadap temuan penelitian terkait Nilai karakter siswa yang dihasilkan dalam program lisa, libra, patujar yang diterapkan di Smpn 1 Cilamaya Wetan.

Nilai karakter siswa yang dihasilkan dalam program lisa, libra, patujar yang diterapkan di Smpn 1 Cilamaya Wetan.

Sebagaimana dipahami bersama bahwa pada prinsipnya setiap program yang dijalankan akan menghadapi masalah, baik masalah yang sifatnya sepele maupun yang kompleks. Hal ini pula yang terjadi dalam pelaksanaan penerapan pendidikan karakter di sekolah SMPN 1 Cilamaya Wetan Kabupaten Karawang. Dimana berdasarkan hasil penelitian yang dilakukan bagaimana nilai karakter siswa yang dihasilkan dalam program lisa, libra, patujar yang diterapkan di Smpn 1 Cilamaya Wetan. Dimana program ini hanya diterapkan di sekolah ini saja yang menjadi perlopor dalam mewujudkan 
dan mendukung program pemerintah penguatan pendidikan karakter.

Pendidikan

formal

memberikan kontribusi dalam

pencapaian akademik, juga membantu membentuk karakter peserta didik. Pendidikan formal yang diselenggarakan oleh sekolah membantu secara sistematis pembentukan peserta didik menjadi lebih baik dari berbagai pembiasaan yang diselenggarakan oleh sekolah. Pembentukan karakter melalui pendidikan formal di mulai dengan pembiasaan disiplin dalam segala bidang. Seperti penegakan peraturan tata tertib sekolah dan disiplin waktu masuk sekolah. Pendidikan informal juga belum membantu dalam penguatan pendidikan karakter terutama dalam lingkungan keluarga. Keluarga belum memberikan kontribusi berarti dalam mendukung pencapaian kompetensi dan pembentukan karakter peserta didik. Karena kesibukan dan aktivitas kerja orang tua yang relatif tinggi, kurangnya pemahaman orang tua dalam mendidik anak di lingkungan keluarga, pengaruh pergaulan di lingkungan sekitar, dan pengaruh media elektronik ditengarai bisa berpengaruh negatif terhadap perkembangan dan pencapaian hasil belajar peserta didik.
Berlandaskan pada UndangUndang Republik Indonesia nomor 20 tahun 2003 tentang Sistem Pendidikan Nasional (UU Sisdiknas) merumuskan fungsi dan tujuan pendidikan nasional yang harus digunakan dalam mengembangkan upaya pendidikan di Indonesia. Pasal 3 UU Sisdiknas menyebutkan, "Pendidikan nasional berfungsi mengembangkan dan membentuk watak serta peradaban bangsa yang bermartabat dalam rangka mencerdaskan kehidupan bangsa, bertujuan untuk berkembangnya potensi peserta didik agar menjadi manusia yang beriman dan bertakwa kepada Tuhan Yang Maha Esa, berakhlak mulia, sehat, berilmu, cakap, kreatif, mandiri, dan menjadi warga negara yang demokratis serta bertanggung jawab".

Salah satu alternatif untuk mengatasi permasalahan tersebut adalah melalui pendidikan karakter terpadu, yaitu memadukan dan mengoptimalkan kegiatan pendidikan informal lingkungan keluarga dengan pendidikan formal di sekolah. Dalam hal ini, waktu belajar peserta didik di sekolah perlu dioptimalkan agar peningkatan mutu hasil belajar dapat dicapai, terutama dalam pembentukan karakter peserta didik. 
Program Pemerintah PPK senada dengan Program Sekolah Lisa Libra

Nilai-nilai utama
disesuaikan
dengan GNRM

\section{Patujar}

\section{Religius}
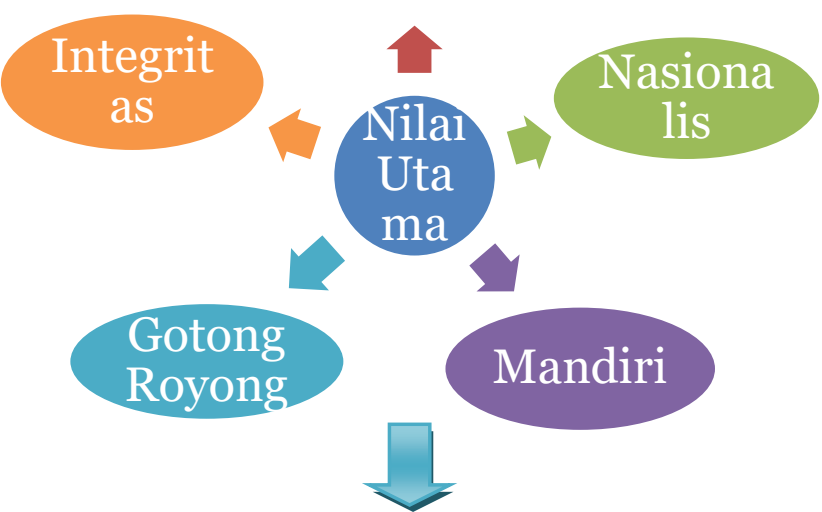

\section{Olah Hati Etika, Olah Pikir Literasi,}

Olah Karsa Estetika, Olah Raga Kinestetika

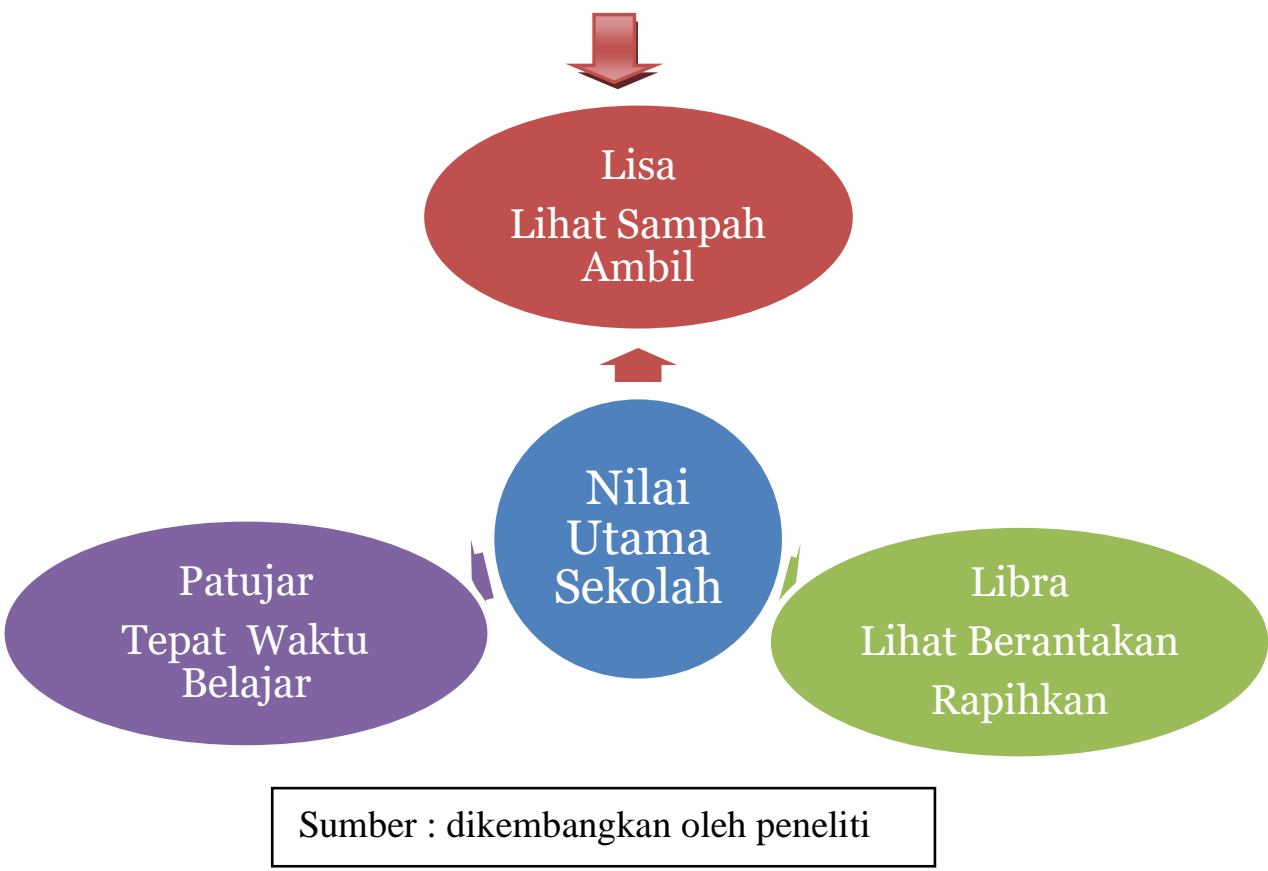

Sekolah juga memadukan program pemerintah yang mencanangkan penguatan pendidikan karakter (PPK) dengan program sekolah lisa, libra dan patujar yang menjadi unggulan sekolah untuk mengiplementasikan

penguatan pendidikan karakter yang akan membentuk karakterk siswa dimasa yang akan datang lewat pembiasaan semenjak dini.

Secara konseptual program lisa, libra dan patujar yang digulirkan oleh kepala sekolah. Mengharapkan 
sekolah yang mempunyai disiplin waktu tinggi dengan ditaati oleh seluruh elemen sekolah, secara sederhana ketika seluruh lapisan sekolah sudah mempunyai rasa disiplin tinggi tentunya akan di ikuti rasa tanggung jawab tinggi dalam diri, dimana ketika melaksanakan peraturan sekolah atau program sekolah tentunya akan bisa bekerjasama dengan baik dan terciptanya tujuan yang diharapkan. Dengan adanya kolaborasi dari program sekolah lisa, libra dan patujar antara program pemerintah mengenai peguatan pendidikan karakter, diharapkan akan saling mendukung untuk mencapai tujuan yang diharapkan yaitu generasi penerus bangsa yang mempunyai karakter baik.

Program lisa libra patujar digulirkan oleh kepala sekolah menengah pertama negeri 1 cilamaya wetan pada tahun ajaran 2016/2017, menjadi program unggulan sekolah yang merupakan inovasi kepala sekolah dalam rangka membantu mewujudkan program pemerintah yaitu penguatan pendidikan karakter.

Nilai karakter siswa yang dihasilkan dalam program lisa libra patujar yang baru berjalan satu tahun yang diharapkan bisa membentuk karakter peserta didik dengan baik, diantaranya nilai karakter baik siswa yaitu rasa disiplin, tanggung jawab, peduli sesama dan peduli lingkungan. Walau dirasa masih sangat kurang karena baru berjalan satu tahun jadi belum bisa terlihat pembentukan karakter yang diharapkan sesuai dengan tujuan lisa, libra dan patujar. Akan tetapi nilai karakter yang dihasilkan oleh siswa baru sebatas pembiasaan dini dan masih penuh dengan pengawasan berbagai pihak. Tidak hanya menjadi tanggung jawa badan pengawas yaitu OSIS tetapi juga menjadi tanggung jawab bersama seluruh elemen sekolah.

\section{Nilai Karakter Siswa Lisa Libra Patujar}

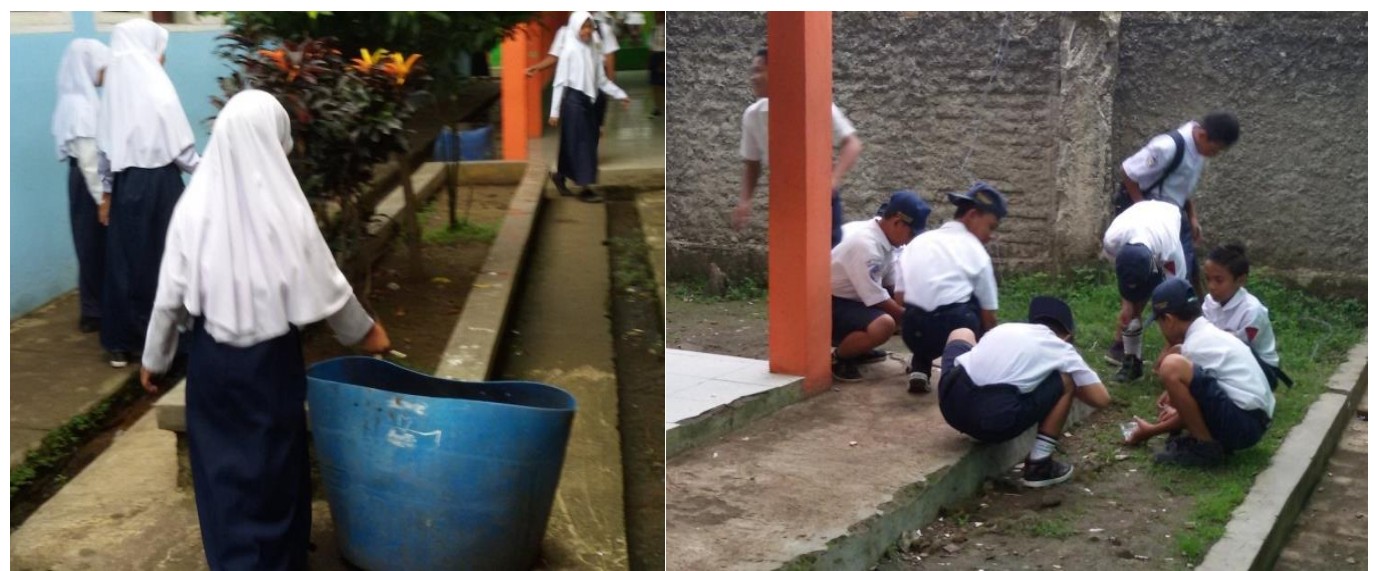

Melihat realitas di sekolah, nilai yang dihasilkan dalam program lisa libra patujar baru sebatas pembiasaan peserta didik, karena disadari betul sebuah program tidak akan langsung berjalan sesusai dengan rencana karena tentu adanya pro dan kontra yang terjadi ketika sebuah kebijakan itu diterapkan. 
Hakikatnya sebuah bangsa tidak akan berubah maju tanpa bangsanya sendiri yang merubah kearah kemajuan, karena itu letak kekuatan pembentukan karakter berakar dari pembiasaan warga sekolah itu sendiri. Setiap sekolah bahkan pemerintah harus mampu mengintegrasikan diri dengan situasi dan kondisi sekolah sesuai dengan wilayahnya. berlandaskan pada Peraturan No 20 Tahun 2003 pasal 3 tentang Pendidikan nasional berfungsi :

\section{"mengembangkan}

kemampuan dan membentuk watak serta peradaban bangsa yang bermartabat dalam rangka mencerdaskan kehidupan bangsa, bertujuan untuk mengembangkan potensi peserta didik agar menjadi manusia yang beriman dan bertakwa kepada tuhan yang maha esa, berakhlak mulia, berilmu, cakap, kreatif, mandiri, dan menjadi warga negara yang demokratis serta bertanggung jawab".

Pada prinsipnya peneliti dapat menyatakan bahwa nilai karakter mengandung kebaikan bagi kehidupan peserta didik. Nilai karakter dianggap sebagai pembentukan diri yang berujung pada terbentuknya rasa kesatuan nasional. Dengan adanya pembiasaan di tahun pertama bergulirnya DAFTAR REFERENSI

Alwasilah, A.C. 2012. Pokoknya Kualitatif. Jakarta: Pustaka Jaya

Doni Kusuma A. (2007). Pendidikan Karakter. Jakarta :Grasindo.

Gay, L.R, dkk. (2009). Educational Research Competencies for Analysis Application (Ninth program lisa libra patujar dalam diri peserta didik mengenai rasa disiplin, tanggung jawab, peduli sesama dan peduli lingkungan, cepat atau lambat pembentukan karakter dalam diri mereka akan terbentuk dengan adanya pembiasaan semenjak dini dan dilaksanakan setiap hari.

\section{SIMPULAN}

Nilai karakter merupakan salah satu aspek yang harus menjelma dan dilakukan dalam setiap aktivitas manusia, termasuk di dalamnya sebagai arah dan orientasi program penguatan pendidikan karakter yang menjadi paradigma pembangunan nasional. Nilai karakter harus ditanamkan semenjak dini karena akan membentuk pembiasaan diri dalam melaksanakan nilai-nilai karakter dalam kehidupan tanpa mereka sadari dan secara perlahan akan membentuk karakter baik dalam diri peserta didik sebagai generasi penerus bangsa yang rentan dengan terjangan arus globalisasi, yang akan membawa mereka secara perlahan meninggalkan jatidiri bangsa Indonesia dengan hidup apatis. Oleh karenanya pembentukan karakter semenjak dini perlu dilakukan oleh berbagai pihak salah satunya program lisa libra patujar yang digulirkan oleh kepala sekolah smpn 1 cilamaya wetan dalam mewujudkan program pemerintah Penguatan Pendidikan Karakter (PPK).

Edition). New Jersey: Upper Saddle River

\section{Sumber Jurnal, Dokumen dan Internet}

Agenda Nawacita No 8 Melakukan revolusi karakter bangsa melalu penataan kembali kurikulum pendidikan 
nasional tersedia dalam http://politik.rmol.co/read/20 14/05/21/156040/InilahNawa-Cita,-SembilanAgenda-Prioritas-Jokowi-JK-

Fadloli, A. 2016. Penguatan Pendidikan Karakter di Smpn 1 Cilamaya Wetan. Tersedia dalam

http://ahmadfadloli.blogspot. co.id/2016/11/penguatanpendidikan-karakter-di-smpn$\underline{1 . h t m l}$
Kemendikbud. 2017. 18 Nilai Karakter Bangsa.

Permendikbud No 23 tahun 2015 tentang penumbuhan budi pekerti.

Permendikbud Nomor 23 Tahun 2017 tentang Hari Sekolah

Peraturan Presiden No 87 tahun 2017 tentang Penguatan Pendidikan Karakter.

UU No 20 Tahun 2003 Pasal 3 Tentang Sistem Pendidikan Nasional 